\title{
VALUE CHAINS ANALYSIS ANALYSIS OF ORGANIC VEGETABLES (Case Study at Mulyo Santoso Farmer Group in Sukun District of Malang City)
}

\author{
Harmawati Haddas $^{1}$, Ratya Anindita ${ }^{2}$, Syafrial $^{2}$ \\ 1 Master's Degree, Post Graduation Program of Agriculture Economics, University of Brawijaya, Indonesia \\ 2 Lecturer of agricultural Socio Economics Department, University of Brawijaya, Indonesia \\ * Corresponding author: armelchan16@gmail.com
}

\begin{abstract}
Increased income and healthy lifestyle trend encourage people to switch to consuming nonorganic food products to organic food products. This encourages producers in developing organic vegetable business. This research was conducted for the development of organic vegetable business by using value chain analysis. Respondent determination was done by census as many as 30 farmers of organic farming at MulyoSantoso Farmer Group in Malang City, and the determination of merchant respondents using snowball sampling. The results show that farmers earn the smallest margin compared to other actors this is because the price received by farmers is determined by the trader. Organic vegetable marketing channel there are four kinds of channels, where farmers who can sell directly to consumers will get the highest profit. This is also related to the efforts of farmers in increasing the added value in processing vegetables into chips and sauces, where farmers are able to increase added value then the profits are also increased. The results of Benchmarking and Upgrading indicate that increasing the added value and capability of farmers to increase production capacity and harvesting the utilization of technology needed to reduce losses post-harvest.
\end{abstract}

Keywords: organic vegetables, margins, added value

\section{INTRODUCTION}

The government through the Ministry of Agriculture has been promoting the program "Go Organic" since 2010 ". In 2015 in accordance with Program Nawacita for food program Ministry of Agriculture has launched the development of 1000 Organic Village several commodities other than rice, namely horticultural commodities, food commodities, and plantation commodities.

The total area of organic land in Indonesia is $76,013.20$ hectares in 2014, most of this organic land is spread in Java Island, with main commodities such as vegetables, coffee, cashew, tea and organic rice. Increasing consumer demand for organic food, especially organic vegetables, encourage producers to do organic farming. This study would like to see how improving the economy through value chain analysis approaches can help farmers in the organic vegetable value chain activities as well as the role of government through policies that strengthen farmers' market access so that farmers earn higher income and highly competitive products. (Kaplinsky and Morris, 2000).

One of the factors that helps in increasing the value of products in the value chain is technology and information in marketing the product, knowing the consumer's wishes, and making decisions (Chan 2007). Good information when combined with technology will be able to drive marketing (Pietrobelli and Rabellotti 2011). Regional employment creation and income are constantly referring to the value chain with an understanding of what the market will pay (Stringer, 2007; Stringer 2009). Therefore, this study aims to analyze the value chain of organic vegetables by mapping from main actors to end customers along the chain, determining market segmentation with and how organic farmers' vegetables can be improved by doing Benchmarking and Upgrading. 


\section{RESEARCH METHODS}

The object of this research is farmers who are members of farmer group Mulyo Santoso and partner farmers who cooperate with farmer group Mulyo Santososo. Technique of sampling farmers by census with the number of farmers respondents as much as 30 people next the determination of respondents' merchant done with Snowball Sampling. Data collection is done by focusing on the actors involved with interview technique (indepth interview) and questionnaire distribution, supporting data in can from related institution. Value chain analysis in use is a concept of the concept of ACIAR (2012) and Kaplynski Morris (2001). The concept of the value chain was originally popularized by Porter (1985); then, it is developed with the Wallerstein concept of the commodity chain (Raikes et al, 2000; Bair, 2005). As well as Gereffi's (2003) and Humphrey's (2002) incorporated with the Global Value Chain (GVC) Concept. McGregor and Stice (2014), Value Chain Analysis is a tool for seeing each step as well as looking at actors along the value chain and identifying the weaknesses of both so that they can be resolved and provide an opportunity for income generation for all actors involved in the chain. Lazarrini et al. (2001) developed the Netchain Concept to show the relationship between horizontal and vertical dimensions in the value chain.

\section{RESULTS AND DISCUSSION}

\section{Value Chain Analysis of Organic Vegetables}

\section{Mapping of Value Chain}
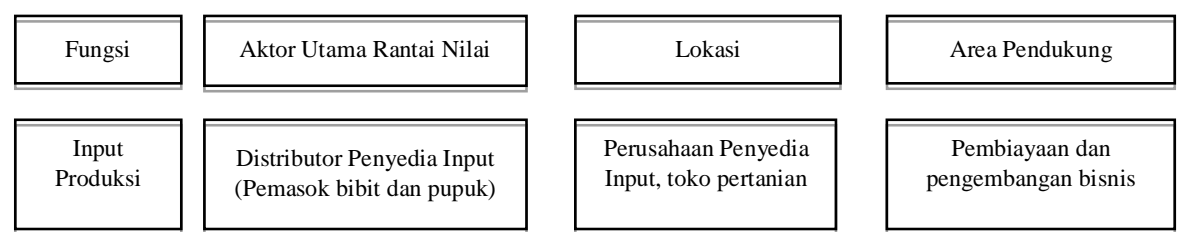

Aktor Pendukung
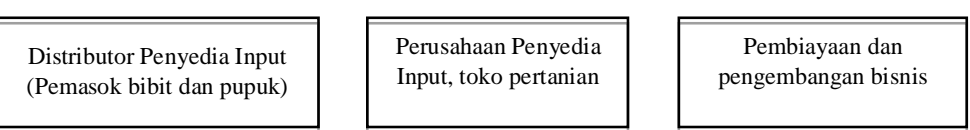

Perusahaan Penyedia Input

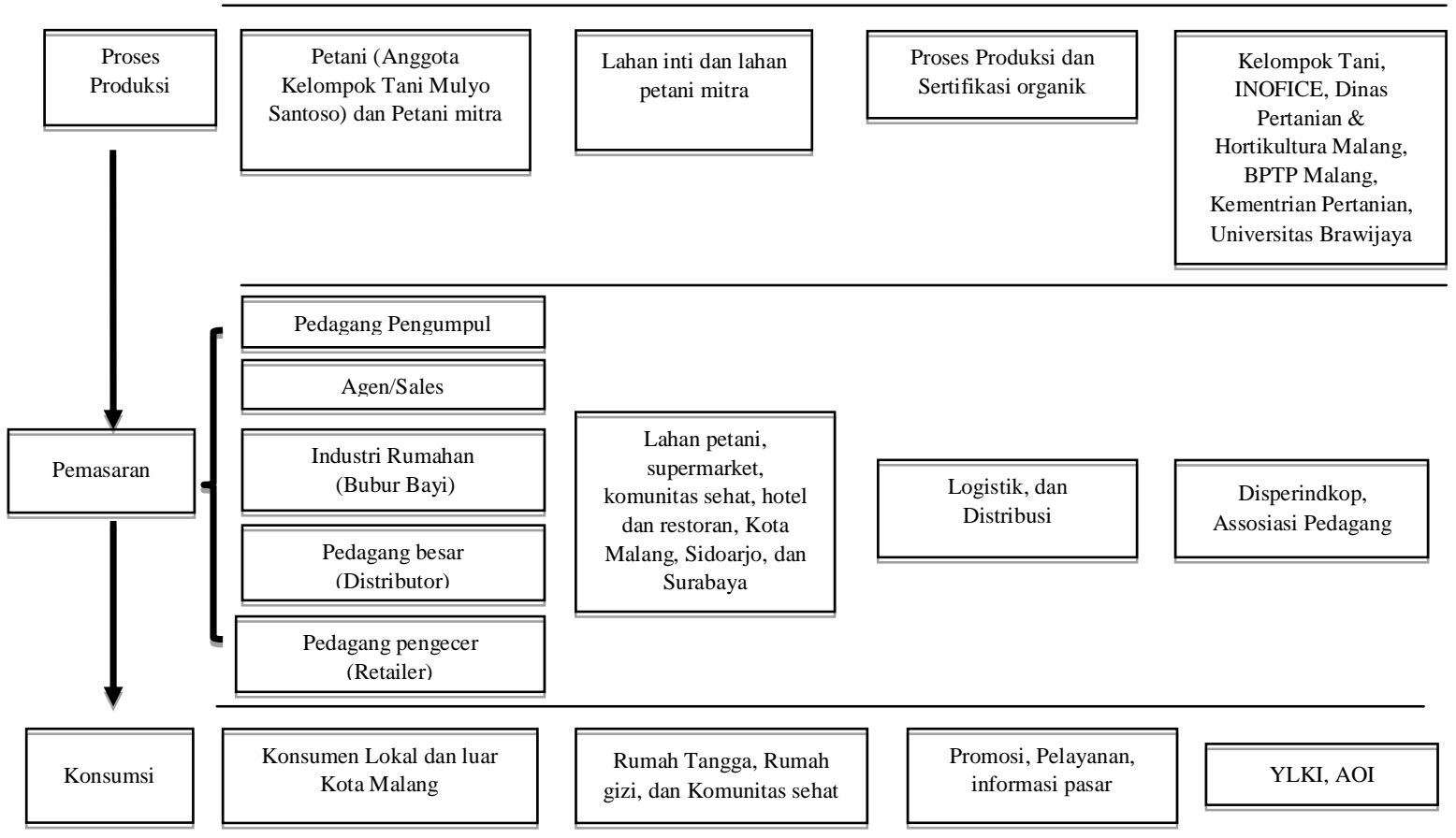

Figure 1. Mapping of Organic Vegetable Value Chain of Mulyo Santoso Farmers Group

The mapping of the organic vegetable value chain can be seen in Figure 1. The core process mapping flow in the organic vegetable value chain starts from the supplier / input provider as a supplier of seeds and fertilizer from the input supply distributors as well as from the farmers themselves providing the production inputs, then the production process is carried out by farmers Mulyo 
Santoso and partner farmers who have established cooperation in organic vegetable farming. Market participants are conducted by collecting traders, agents / sales, wholesalers, processed industries and retailers. Distributors in addition to supplying to Restaurants and Hotels in Surabaya also supply to retailers whose marketing areas are mostly located outside Kota Malang for retailers located in Surabaya area such as supermarket plaza and hypermart royal Surabaya, while the area of home industry (pulp baby) is in Sidoarjo, the industry is included in the category of small and medium enteIDRrises with the sale of ready-made baby porridge using organic vegetable base. Farmers also conduct direct selling (direct sales) to consumers who come directly to plantation land to buy organic vegetable.

\section{Marketing Channel Mapping And Product Volume}

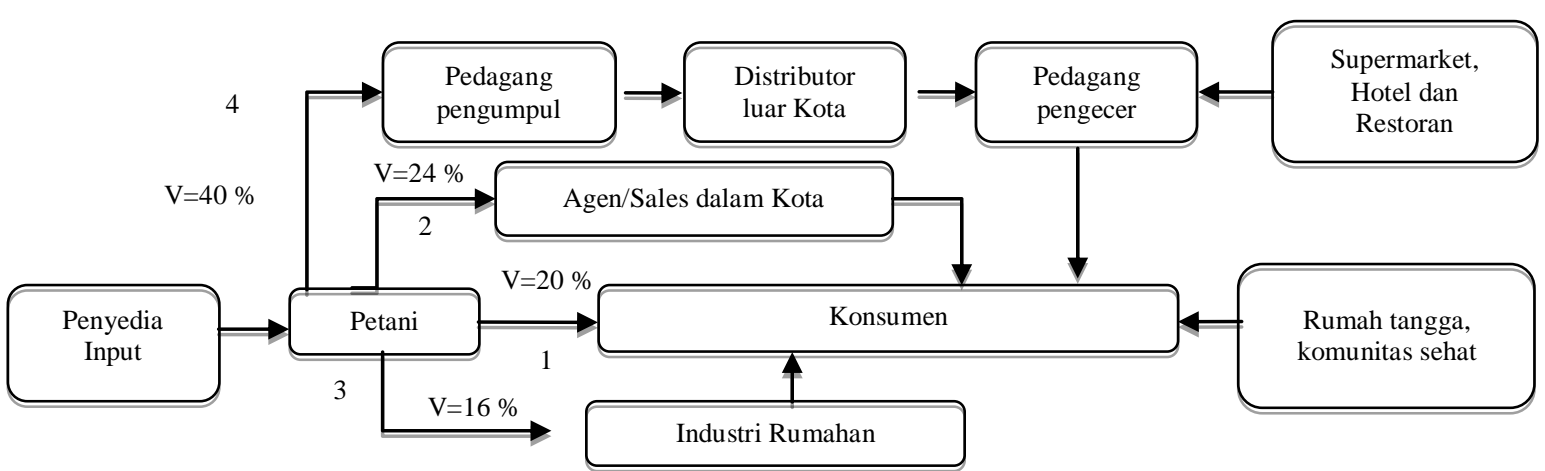

Figure 2. Mapping of product volume and marketing channels of organic vegetable

Based on the observation in the field, the marketing channel of organic vegetables poktan mulyo santoso is as follows:

1. Marketing Channel $1=$ Farmer - Consumer (Direct Sales)

2. Marketing Channel $2=$ Farmer - Agent $/$ Sales Consumer

3. Marketing Channels $3=$ Farmers - Home Industry - Consumers

4. Marketing Channels $4=$ Farmers - Overseas Distributors - Retailers / Retailers - Consumer From the figure above the highest volume of vegetable shipment is in the distributor of $40 \%$ this is because the distributors do the next marketing to the retail (supermarket) where consumers who buy in supermarkets mostly come from households, hotels and restaurants, the volume of consumer purchases directly buy to the farmer for 20 percent, agency / sales $24 \%$ and the lowest of the home industry by $16 \%$.

\section{Cost Mapping and Margin Marketing}

Costs incurred by farmers for fixed costs and variable costs of IDR 5,530,000, -, total farmer receipts of IDR 21.6 million, - and income earned by farmers of IDR 16,070,000, - (Table 1). R / C results of farmers in get 2.9. If the ratio of $\mathrm{R} / \mathrm{C}$ is less than 1 , then the farm is feasible. So organic vegetable farms provide benefits and it is feasible to develop more.

Tabel 2. Table average revenue, income, and R/C of Organic Vegetable Farming

\begin{tabular}{clr}
\hline No & \multicolumn{1}{c}{ Description } & \multicolumn{1}{c}{ Amount } \\
\hline 1 & Cost incurred & $2,200,000$ \\
& - Fixed cost (IDR) & $3,330,000$ \\
& - Variable cost (IDR) & $5,530,000$ \\
& - Total cost (IDR) & $21,600,000$ \\
2 & Reception (IDR) & $16,070,000$ \\
3 & Income (IDR) & 2.9 \\
4 & R/C Ratio &
\end{tabular}


Table 2. Results of Cost, Profit, and Margin Analysis The marketing of organic vegetables of each actor

\begin{tabular}{lccccccc}
\hline Value Chain Actor & $\begin{array}{c}\text { Production } \\
\text { cost (IDR) }\end{array}$ & $\begin{array}{c}\text { Purchase } \\
\text { (IDR) }\end{array}$ & $\begin{array}{c}\text { Cost } \\
\text { (IDR) }\end{array}$ & $\begin{array}{c}\text { Total Cost } \\
\text { (IDR) }\end{array}$ & Seller (IDR) & $\begin{array}{c}\text { Profit } \\
\text { (IDR) }\end{array}$ & $\begin{array}{c}\text { Margin } \\
\text { (IDR) }\end{array}$ \\
\hline Farmers & 3,500 & & & & 8,500 & 5,000 & \\
Collector Dealer & & 8,500 & 3,000 & 11,500 & 22,500 & 11,000 & 14,000 \\
Agent / Sales & & 22,500 & 3,000 & 25,500 & 30,000 & 4,500 & 7,500 \\
Wholesalers & & 15,000 & 5,000 & 20,000 & 28,000 & 8,000 & 13,000 \\
Merchant Dealer & & 28,000 & 5,000 & 33,000 & 50,000 & 17,000 & 22,000 \\
Consumer & & 50,000 & & & & & \\
\hline
\end{tabular}

Source: Primary data (analyzed)

From table 2 it is known that the lowest margin obtained by farmers is IDR 5,000, -, this is because the farmer only as Price Taker only as the recipient of the price determined by the trader. The highest margin earned by retailers is IDR 22,000, -, retailers incur greater transportation costs related to farmland distance to consumers and storage costs for cold storage (refrigerator).

\section{Product Segmentation with Critical Success Analysis Factor (CSF's)}

Critical success factor's analysis (CSF's) is used to determine the success factors of the company or failure obtained during organic farming, and which variables must be improved to improve the performance of organic vegetable farming. There are ten variables in critical success factors in this study, namely: Certification Label, Price, Freshness, Quality, Delivery, Promotion, Ease of Getting Vegetable Products in the Market, Stock, Standard, and Packaging. (Table 3).

From the research result in Table 3 and Figure 3 , it is known that at the farmer's level a very important factor is that this certificate is related to the level of income of farmers, with certification affecting the interest of traders and consumers to buy organic vegetables, then the freshness, quality and packaging attributes also influence consumers to keep buying organic vegetable products Farmers do this thing by farmers to maintain consumer confidence in their organic vegetable products.
Furthermore, at the consumer attribute level with the highest gap value of 4.8 perceptions of freshness and quality, consumers want organic vegetables that are kept fresh, promotion and stock attributes with a 4.6 gap value also affect consumer interest, for that farmers should promote genjar and increase production capacity to the maximum so that the stock of organic vegetables can meet consumer demand.

Table 3. Comparison of Critical Success Factor's (CSF's) value between farmers and consumers

\begin{tabular}{rlccc}
\hline No & \multirow{2}{*}{$\begin{array}{c}\text { Attribute } \\
\text { CSF's }\end{array}$} & \multicolumn{2}{c}{ Perseption } & \multirow{2}{*}{ Gap } \\
\cline { 3 - 4 } 1 & Certification & 4.8 & Consumers & \\
2 & Price & 4.33 & 4 & 0.8 \\
3 & Freshness & 4.67 & 4.8 & 0.33 \\
4 & Quality & 4.46 & 4.8 & 0.13 \\
5 & Delivery & 4.13 & 4.067 & 0.06 \\
6 & Promotion & 4.53 & 4.6 & 0.07 \\
7 & Ease of & 4.53 & 4.73 & 0.2 \\
& Getting Veg. & & & \\
& Products & & & \\
8 & Stock & 4.4 & 4.6 & 0.2 \\
9 & Standard & 4.53 & 4.47 & 0.06 \\
10 & Packaging & 4.53 & 3.87 & 0.66 \\
\hline
\end{tabular}

Source: Primary data (analyzed) 


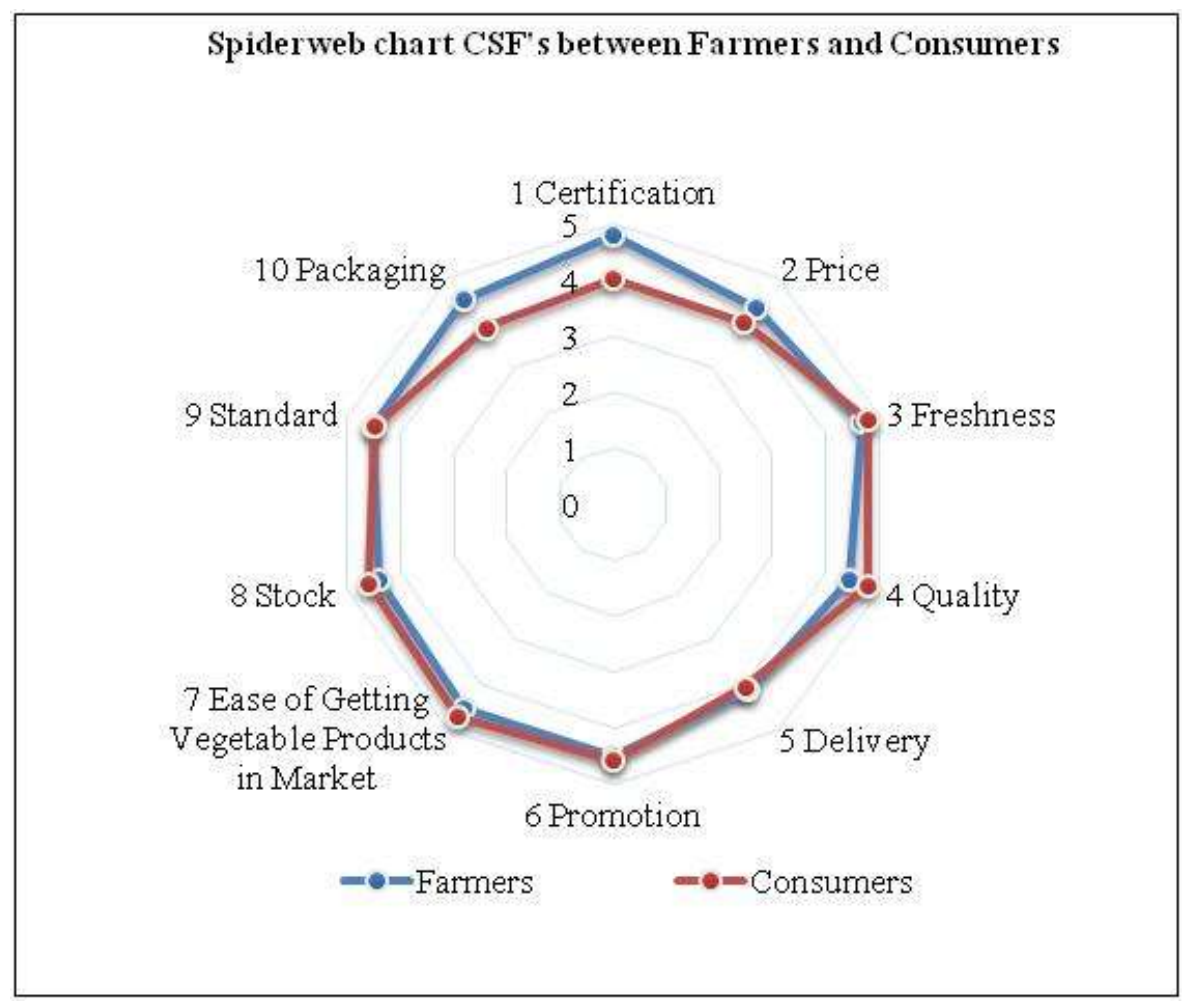

Figure 3. Spider-web results between farmers' perceptions and organic vegetable consumers

\section{Benchmarking}

Table 4. Results of Organic Vegetable benchmarking between Mulyo Santoso Farmers Group and Organic Vigur Farmers Group

\begin{tabular}{|c|c|c|}
\hline Benchmark Parameters & Mulyo Santoso Farmer Group & Organic Vigur Farmer Group \\
\hline Price* & IDR 4,500. - / pack 200 gr & IDR 7,500, - / pack $200 \mathrm{gr}$ \\
\hline Certification Agency & Certified LSPO INOFICE & LESO LSPO certified \\
\hline Product Differentiation & Fresh organic vegetables & $\begin{array}{l}\text { Fresh organic vegetables, organic rice } \\
\text { and processed products }\end{array}$ \\
\hline Readiness In The Market & Stock is always available in the market & Stock sometimes not available \\
\hline Distribution channel & $\begin{array}{l}\text { Consumers in and outside Malang city, } \\
\text { baby slurry industry }\end{array}$ & $\begin{array}{l}\text { Restaurant, local supermarket, small } \\
\text { gift shop }\end{array}$ \\
\hline Marketing Area & Malang, Surabaya and Sidoarjo & Malang city \\
\hline Diversity of Vegetables & Many types & Limited \\
\hline Quality & Good & Good and bad \\
\hline Promotion & $\begin{array}{l}\text { Market farm, direct communication, } \\
\text { and online market in promoted by } \\
\text { agent/sales }\end{array}$ & $\begin{array}{l}\text { Direct communication, brochures, } \\
\text { social media, bazaars and domestic } \\
\text { exhibitions }\end{array}$ \\
\hline Design on the packaging & $\begin{array}{l}\text { Packaging is divided into } 3 \text { levels for } \\
\text { direct consumers, sales / agents and } \\
\text { distributors }\end{array}$ & Has a distinctive feature of the product \\
\hline Turnover & IDR 60,000,000. - / month & IDR $35,000,000,-$ / month \\
\hline Target & $\begin{array}{l}\text { New markets domestically and abroad, } \\
\text { opened a restaurant with an all-organic } \\
\text { menu }\end{array}$ & $\begin{array}{l}\text { Markets out of the poor city, opened a } \\
\text { special training organic farming }\end{array}$ \\
\hline
\end{tabular}

Source: Primary data (analyzed) 
Based on Table 4 above, it shows that there is a significant difference between the Mulyo Santoso farmer group and the Vigur Organic farming group, in terms of price. The price offered by Multan Santoso farmers is cheaper than the Organic Vigurant Poktan, besides in terms of marketing where the marketing area and product availability in the market Mulyo Santoso is superior to its competitors, this is because the land area owned by Mulyo Santoso and the partnership system are carried out by farmer groups outside the city of Malang so that the supply of organic vegetables is more widely available in the market, so the turnover received is more than competitors. In contrast to competitors, Mulyo Santoso Poktan relied more on marketing through sales / agents and from the mouth of consumer mouth, compared to Mulyo santoso Poktan, Vigur Organik Poktan in the use of information technology through social media, brochures, following a national-level exhibition for the promotion of organic vegetable products, besides the Organic Vigurant Poktan is superior in differentiation Products not only sell in vegetables in the fresh form but also in the form of processed (vegetable chips) and products are not limited to vegetables but also Organic rice, organic rice crackers, organic soy sauce, sauce and organic sauce and etc. Mulyo Santoso Poktan does not use social media in terms of marketing his products due to providing sales / agent opportunities to promote his own organic vegetables. This is because Mulyo Santoso Poktan has a desire to provide opportunities for those who partner with him to expand product marketing (empowering the people around him).

\section{Upgrading of Value Chain}

Table 5. Improvement of the Value Chain/Upgrading for each actor

\begin{tabular}{|c|c|c|}
\hline $\begin{array}{l}\text { Value Chain } \\
\text { Actor }\end{array}$ & $\begin{array}{l}\text { Barriers in the } \\
\text { value chain }\end{array}$ & Value Chain Repair / Upgrading \\
\hline \multirow{4}{*}{ Farmers } & $\begin{array}{l}\text { Market } \\
\text { Access }\end{array}$ & $\begin{array}{l}\text { - Increase production capacity in order to reach new markets } \\
\text { - Improve partnerships with partner farmers, traders and consumers } \\
\text { - Establish cooperation with modern market } \\
\text { - Participation in promotions through local and national exhibitions } \\
\text { - Pricing together }\end{array}$ \\
\hline & Technology & $\begin{array}{l}\text { - Post-harvest technology innovation so as not to lose much of the harvest } \\
\text { during the process of sorting and grading } \\
\text { - Application of appropriate technology in the production process } \\
\text { - Training of processed product development } \\
\text { - The use of information technology through social media }\end{array}$ \\
\hline & Quality & - Improve product quality with a focus on what consumers want. \\
\hline & Management & - Introduction of organic food quality standards that meet national and \\
\hline \multirow{3}{*}{ Marketer } & Transportation & $\begin{array}{l}\text { - Speed of delivery for vegetables to reach consumers in a state of freshness. } \\
\text { - Conditioning the travel route so that delivery can be accelerated. }\end{array}$ \\
\hline & Market & - Open new markets in order to reach consumer demand from other regions \\
\hline & Access & - Increase promotion in order to attract consumers \\
\hline \multirow[t]{3}{*}{ Consumer } & $\begin{array}{l}\text { Information } \\
\text { Transfer }\end{array}$ & $\begin{array}{l}\text { - Need to provide information to consumers related to national certified } \\
\text { organic food. }\end{array}$ \\
\hline & Market & - Increase the stock in order to meet consumer demand \\
\hline & Access & $\begin{array}{l}\text { - Increasing the diversity of organic vegetables in the market } \\
\text { - The price offered in the market is not too expensive }\end{array}$ \\
\hline
\end{tabular}


Table 5. Improvement of the Value Chain/Upgrading for each actor (Continue)

\begin{tabular}{|c|c|c|}
\hline $\begin{array}{l}\text { Value Chain } \\
\text { Actor }\end{array}$ & $\begin{array}{l}\text { Barriers in the } \\
\text { value chain }\end{array}$ & Value Chain Repair / Upgrading \\
\hline \multirow[t]{2}{*}{$\begin{array}{l}\text { Supporting } \\
\text { Institutions }\end{array}$} & Regulation & $\begin{array}{l}\text { - Establishment of good government regulation at central and regional level in } \\
\text { the ease of process of obtaining organic food certificate } \\
\text { - Need for making road map of organic agriculture development activities } \\
\text { - Increased access to capital sources in the provision of soft credit schemes } \\
\text { - Increased field extension, especially extension of organic agriculture in } \\
\text { assisting farmers in the development of organic farming } \\
\text { - Training policies and fostering of farmers, especially the improvement of } \\
\text { product quality so that the products produced by farmers can have a } \\
\text { competitive advantage in the domestic market. }\end{array}$ \\
\hline & organization & $\begin{array}{l}\text { - Establishment of organic farming containers / associations at farmers and } \\
\text { traders level to accommodate the aspirations of each actor in the value chain } \\
\text { and establish communication among stakeholders } \\
\text { - The need to establish an institution / cooperative that can assist farmers in the } \\
\text { development of organic vegetables }\end{array}$ \\
\hline
\end{tabular}

\section{CONCLUSION AND SUGGESTION}

\section{Conclusion}

The main actors in the organic vegetable value chain are Input Providers, farmers, collecting traders, agents/sales, distributors, retailers/ supermarkets, and consumers. Organic vegetable marketing is located in Malang, Sidoarjo and Surabaya.

The marketing channel consists of 4 channels. From the Margin mapping result, it is known that the collector's margin is IDR 14,000 , agent / Sales IDR 7,500, distributor IDR 13,000, and at the retailer level of IDR 22,000. Ten variables in the critical success factor are certification label, price, freshness, quality, delivery, promotion, ease in accessing vegetable products, stock, standard, and packaging. Moreover, the attributes of price, quality and promotion greatly affect the demand from consumers. While at the farm level a very important factor is the certificate this is related to the level of sales of farmers in the market while the lowest is delivery.

\begin{abstract}
Suggestions
Improved value chains and improvement opportunities can be done by looking at the obstacles faced by the actor. At the farm level is increasing skills and knowledge about organic vegetable cultivation, development of processed products, cooperate with modern market. Traders should do the speed of delivery so that consumers can enjoy fresh vegetables in addition to promoting in order to attract consumers. At the consumer level things need to be done by adding stock and multiplying the diversity of organic vegetables.

The government and related agencies need to make policies that are beneficial to organic vegetable farmers especially in terms of ease of obtaining organic certificates, ease of access to markets, especially modern markets, pricing information and provision of farming capital, institutional or cooperative establishment that accommodates organic producers, as well as coaching and training on organic farming to increase the competitive advantage of organic vegetable products.
\end{abstract}

\section{ACKNOWLEDGEMENTS}

I am very grateful to my counselor prof. Ir. Ratya Anindita, MS.,PhD and Dr. Ir. Syafrial, MS. for his direction and guidance during the writing of this thesis. 


\section{REFERENCES}

Australian Centre for International Agriculture Research (ACIAR). 2012. Membuat Rantai Nilai Berpihak Pada Kaum Miskin. Buku Pegangan Untuk Praktisi Rantai Nilai. Tabros, Indonesia.

Bair, J. (2005): Global Capitalism and Commodity Chains: Looking Back, Going Forward. Competition \& Change, Vol. 9, No. 2, pp. 153-180.

Chan JO. 2007. A Predictive Analytic Model for Value Chain. Management. Journal of International Technology and Information Management. Vol 6(1): 31-43.

Direktorat Jendral Pengolahan dan Pemasaran Hasil Hortikultura. 2014. Http://hortikultura.pertanian.go.id. Di akses Tanggal 20 April 2017.

Gereffi, Gary, Memedovic, Olga. 2003. The Global Apparel Value Chain: What Prospects for Upgrading By Developing Countries. United Nations Industrial Developing Organization. Vienna.

Humphrey, J. and H. Schmitz. 2002. How Does Insertion in Global Value Chains Affect Upgrading in Industrial Clusters? Regional Studies, 36: 1017-1027.
Kaplinsky, R. and M. Morris (2002): Handbook for value chain research, IDRC http://www.ids.ac.uk/ids/global/pdfs/VchN ov01.pdf. Diakses November 2016

Lazzarini, S.G., 2008. Horizontal and vertical relationships in developing economies: implications from SMEs access to global markets. Academy of Management Journal, 51(2): 359-380.

McGregor, Andrew and Stice, Kyle. 2014. Agricultural Value Chain Guide for the Pacific Islands. Technical Centre for Agricultural and Rural Cooperation (CTA).

Porter, M.E. 1985. Competitive Advantage, Creating and Sustaining Superior Performance. New York: The Free Press.

Raikes, P., Jensen M.F, and S. Ponte (2000): 'Global commodity chain analysis and the French Filiere approach: comparison and critique', Economy and Society, Vol. 29, Issue 3, pp. 390-417.

Stringer, R. 2007. Why a Value Chain Approach is useful for Policy and Practise. Sustainable Food and Wine Value Chains Workshop, 12 November 2007. University of Adelaide 